\title{
Growth and Trends of Non-durable Agricultural Inputs in Eastern Uttar Pradesh: District Level Analysis
}

\author{
Parmeshwar Kushwaha* and Rakesh Singh
}

Department of Agricultural Economics, Institute of Agricultural Sciences,

B.H.U., Varanasi-221005, U.P., India

*Corresponding author

\section{A B S T R A C T}

Keywords

Growth, Trend,

Nitrogen,

Phosphorus and

Potash.

Article Info

Accepted:

04 October 2017

Available Online:

10 December 2017
The present study is conducted on growth rate of nitrogen, phosphorus and potash under of fertilizer groups in Eastern Uttar Pradesh, district of U.P viz. Jaunpur, Pratapgarh and Gorakhpur District were selected purposively. A time series data from 1995-96 to 2014-15 (20 year) of fertilizer groups in study area was analysed. The compound growth rate as well as trend analysis indicated that the growth rate of Nitrogen, phosphorus and potash. The results showed that the growth of fertilizers in study areas varies from (1.6\%) to $(2.9 \%) 1995-96$ to $2014-15$. For sub period II, potash is observed of negative growth rate varies from $(-1.6 \%)$ to $(-11.3 \%)$ in $2005-06$ to 2014-2015 due to reduction of government subsidy on non-urea fertilizers.

\section{Introduction}

India is one of the largest consumers of chemical fertilizer in the world. Overtime the consumption of fertilizers in the country has increased. Fertilizer consumption in India increased from 2.60 million tonnes of nutrients in the year 1974-75 to 12.7 million tonnes in 1990-91 to 25.15 million tonnes in 2008-09 and to 26.75 million tonnes in 201516. In India has been increasing over the years and today India is the third largest producer of fertilizer after China and USA as well as second largest consumer after China in the world. India accounted for about 14 per cent of the world consumption and about 12 per cent of the global production in 2011, total fertilizer consumption in the country was
26.75 million tonnes in 2016-17.Importance of fertilizers in yield improvement, which is essential for achieving increased agricultural production, further increases because there is little scope for bringing more area under cultivation as well as majority of Indian soils are deficient in many macro and micro nutrients. The application of essential plant nutrients, particularly major and micronutrients in optimum quantity and right proportion, through correct method and time of application, is the key to increased and sustained crop production. Although Uttar Pradesh has diverse types of soil but most of them are deficient in nitrogen and phosphorus. Over the years, the increased 
usage of chemical fertilizers has played a significant role in increasing the farm productivity. The increase in food grain production is Uttar Pradesh due to the use of fertilizers, improved seeds, pesticides and mechanization of agriculture. Though the mechanization has played a key role in increasing food production and it plays a pivotal role in the national economy. The role of fertilizer in agricultural production has increased overtime due to scarcity of land resource in the country. There is necessity of using balanced doses of inputs including fertilizer to an unit of land to get the most optimum level of production.

Therefore it is important to understand fertilizer use behavior in the country over time as well as role of factors influencing fertilizer consumption at the national and regional/state level because intensity of fertilizer use varies from state to state and area to area.

\section{Materials and Methods}

\section{Data}

The study on growth rate of Nitrogen, Phosphorus and Potash under of Fertilizer groups in Eastern Uttar Pradesh major producing district of U.P viz. Jaunpur District, Pratapgarh and Gorakhpur District were selected purposively.

Twenty years of time series data on Nitrogen, Phosphorus and Potash under of Fertilizer groups were taken from the period (1995-96 to 2014-15) from the Department of Agriculture Uttar Pradesh and Sankhikiya Patrika Further, study period was divided into three similar sub periods for the analysis of Nitrogen, Phosphorus and Potash in Eastern Uttar Pradesh. Sub periods were made for the Nitrogen, Phosphorus and Potash under of Fertilizer groups as follow:
Sub Period I (1995-96 to 2004-05

Sub Period II (2005-06 to 2014-15)

Sub Period III (1995-96 to 2014-15)

\section{Analytical tool}

Compound growth rates in nitrogen, phosphorus and potash under of fertilizer groups in Eastern Uttar Pradesh were estimated by using the exponential growth function of the form:

$Y_{t}=a b^{t}$

Where,

$Y_{t}=$ dependent variable for which growth rate is estimated

$\mathrm{a}=$ intercept

$\mathrm{b}=$ regression coefficient

$\mathrm{t}=$ time variable

The growth rate coefficient (b's) was computed by transforming the equation in log form

$\log Y_{t}=\log a+t \log b$

The values of ' $a$ ' and ' $b$ ' were estimated by using ordinary least squares estimation technique. Thus, compound growth rate $(\mathrm{g})$ in per cent was computed as

$\mathrm{g}=$ Antilog $[(\log \mathrm{b}-1) * 100]$

\section{Results and Discussion}

\section{Growth rates of distribution of fertilizer (Metric Ton) in Jaunpur}

The compound growth rates of fertilizer in Jaunpur district for the sub period I (1995-96 to 2004-05), sub Period II (2005-06 to 2014- 
15) and overall Period (1995-96 to 2014-15) were worked out and depicted in Table 1.

The results of CGR model for distribution of Fertilizer during 1995-96 to 2014-15 is presented in Table 1 indicates that the Nitrogen, Phosphorus and Potash under of Fertilizer groups a significant and positive growth rate as a whole period 1995-96 to 2014-15 in Jaunpur district. The highest growth rate in Potash distribution was observed in sub period I (13.8\%) and lowest growth rate in sub period II (-1.6\%) (Fig. 1).

Nitrogen Distribution was observed a significant and highest growth rate in the sub period II (3.2\%) and lowest in sub period I $(0.9 \%)$. Phosphorus with highest growth rate got significant and positive in sub period I $(4.4 \%)$ and lowest in sub period II $(2.9 \%)$.
Growth rates of distribution of fertilizer (Metric Ton) in Gorakhpur

It is evident from Table 2 that the Nitrogen, Phosphorus and Potash under of Fertilizer groups a significant and positive growth rate of Nitrogen in sub period I (1.0\%) and II period (1.6).Potash is observed of negative growth rate $(-11.3 \%)$ and significant, period 2005-06 to 2014-15 in Gorakhapur district. In Table 2, Phosphorus distributions recorded positive and significant and highest growth rate in observed in I period $(1.7 \%)$ and lowest growth rate in II period $(-2.3 \%)$. In sub period 1995-96 to 2004-05 of distribution of Potash, growth rate $(3.3 \%)$ observed in positive and significant growth rate and Nitrogen $(1.0 \%)$ observed in lowest growth rate, study period Nitrogen, Phosphorus (1.4 $\%$ ) and Potash (2.0\%) (Fig. 2).

Table.1 Growth rates of distribution of fertilizer (Metric Ton) in Jaunpur

\begin{tabular}{|c|c|c|c|c|}
\hline Item & Particulars & $\begin{array}{c}\text { Sub period I } \\
\text { 1995-96 to 2004-05 }\end{array}$ & $\begin{array}{c}\text { sub period II } \\
\mathbf{2 0 0 5 - 0 6} \text { to 2014-15 }\end{array}$ & $\begin{array}{c}\text { study Period } \\
\text { (1995-96 to 2014-15) }\end{array}$ \\
\hline Nitrogen & Standard Error & 0.13 & 0.007 & 0.004 \\
\hline & F-value & 0.44 & 20.17 & 39.26 \\
\hline & R square & 0.05 & 0.71 & 0.68 \\
\hline & Growth rate & $0.9^{* * *}$ & $3.2^{* * *}$ & $2.3^{* * *}$ \\
\hline Phosphorus & Standard Error & 0.017 & 0.020 & 0.006 \\
\hline & F-value & 6.76 & 2.09 & 48.16 \\
\hline & R square & 0.45 & 0.20 & 0.72 \\
\hline & Growth rate & $4.4^{* * *}$ & $2.9^{* * *}$ & $3.4^{* * *}$ \\
\hline Potash & Standard Error & 0.014 & 0.035 & 0.014 \\
\hline & F-value & 103.30 & 0.207 & 37.14 \\
\hline & R square & 0.92 & 0.25 & 0.67 \\
\hline & Growth rate & $13.8^{* * *}$ & $-1.6^{* * *}$ & $7.9^{* * *}$ \\
\hline Total & Standard Error & 0.012 & 0.010 & 0.004 \\
\hline & F-value & 2.23 & 8.62 & 57.01 \\
\hline & R square & 0.21 & 0.51 & 0.76 \\
\hline & Growth rate & $1.8^{* * *}$ & $3.0^{* * *}$ & $2.9^{* * *}$ \\
\hline
\end{tabular}

Note: ***,**, * indicates significance level at $1 \%, 5 \%$ and $10 \%$ respectively

CGR: Compound growth Rate (per cent per annum) Source: updes.up.nic.in

Note: Calculated by author from the data obtained from economics and statistics Division of Planning Department, Government of Uttar Pradesh 
Table. 2 Growth rates of distribution of fertilizer (Metric Ton) in Gorakhpur

\begin{tabular}{|c|c|c|c|c|}
\hline Item & Particulars & $\begin{array}{c}\text { Sub period I } \\
\text { 1995-96 to 2004-05 }\end{array}$ & $\begin{array}{c}\text { Sub period II } \\
\text { 2005-06 to 2014-15 }\end{array}$ & $\begin{array}{c}\text { Study Period } \\
\text { (1995-96 to 2014-15) }\end{array}$ \\
\hline Nitrogen & Standard Error & 0.004 & 0.027 & 0.007 \\
\hline & F-value & 0.007 & 0.331 & 5.125 \\
\hline & R square & 0.001 & 0.040 & 0.222 \\
\hline & Growth rate & $1.0^{* * *}$ & $1.6 * * *$ & $1.7 * * *$ \\
\hline Phosphorus & Standard Error & 0.017 & 0.030 & 0.009 \\
\hline & F-value & 1.042 & 0.570 & 2.356 \\
\hline & R square & 0.115 & 0.067 & 0.116 \\
\hline & Growth rate & $1.7 * * *$ & $-2.3 * * *$ & 0.019 \\
\hline Potash & Standard Error & 0.027 & 0.049 & 1.071 \\
\hline & F-value & 1.547 & 4.843 & 0.056 \\
\hline & R square & 0.162 & 0.377 & $2.0^{* * *}$ \\
\hline & Growth rate & $3.3 * * *$ & $-11.3 * * *$ & 0.008 \\
\hline Total & Standard Error & 0.013 & 0.028 & 4.391 \\
\hline & F-value & 4.128 & 0.671 & 0.196 \\
\hline & R square & 0.34 & 0.077 & $1.6^{* * *}$ \\
\hline & Growth rate & $0.5 * * *$ & $-2.3 * * *$ & \\
\hline
\end{tabular}

Note: $* * *, * *, *$ indicates significance level at $1 \%, 5 \%$ and $10 \%$ respectively

CGR: Compound growth Rate (per cent per annum)

SE: Standard Errors

Table.3 Growth rates of distribution of fertilizer (Metric Ton) in Pratapgrah district

\begin{tabular}{|c|c|c|c|c|}
\hline Item & Particulars & $\begin{array}{c}\text { Sub period I } \\
\text { 1995-96 to2004-05 }\end{array}$ & $\begin{array}{c}\text { Sub period II } \\
\mathbf{2 0 0 5 - 0 6} \text { to 2014-15 }\end{array}$ & $\begin{array}{c}\text { study Period } \\
\text { (1995-96 to 2014-15) }\end{array}$ \\
\hline Nitrogen & Standard Error & 0.006 & 0.01 & 0.003 \\
\hline & F-value & 4.232 & 0.77 & 33.45 \\
\hline & R square & 0.346 & 0.088 & 0.65 \\
\hline & Growth rate & $1.3 * * *$ & $0.9 * * *$ & $1.7 * * *$ \\
\hline Phosphorus & Standard Error & 0.0261 & 0.025 & 0.009 \\
\hline & F-value & 0.19 & 2.238 & 0.565 \\
\hline & R square & 0.13 & 0.219 & $2.9 * * *$ \\
\hline & Growth rate & $2.8 * * *$ & $3.7 * * *$ & 0.017 \\
\hline Potash & Standard Error & 0.042 & 0.036 & 0.597 \\
\hline & F-value & 6.737 & 0.389 & $8.3 * * *$ \\
\hline & R square & 0.547 & 0.046 & 0.004 \\
\hline Total & Growth rate & $10.4 * * *$ & -2.3 & 36.75 \\
\hline & Standard Error & 0.008 & 0.014 & 0.671 \\
\hline & F-value & 4.64 & 1.038 & $1.6^{* * *}$ \\
\hline & R square & 0.367 & 0.115 & $1.4 * * *$ \\
\hline
\end{tabular}

Note: $* * *, * *, *$ indicates significance level at $1 \%, 5 \%$ and $10 \%$ respectively

CGR: Compound growth Rate (per cent per annum) 
Fig.1 Trend of distribution of fertilizer (Metric Ton) in Jaunpur District

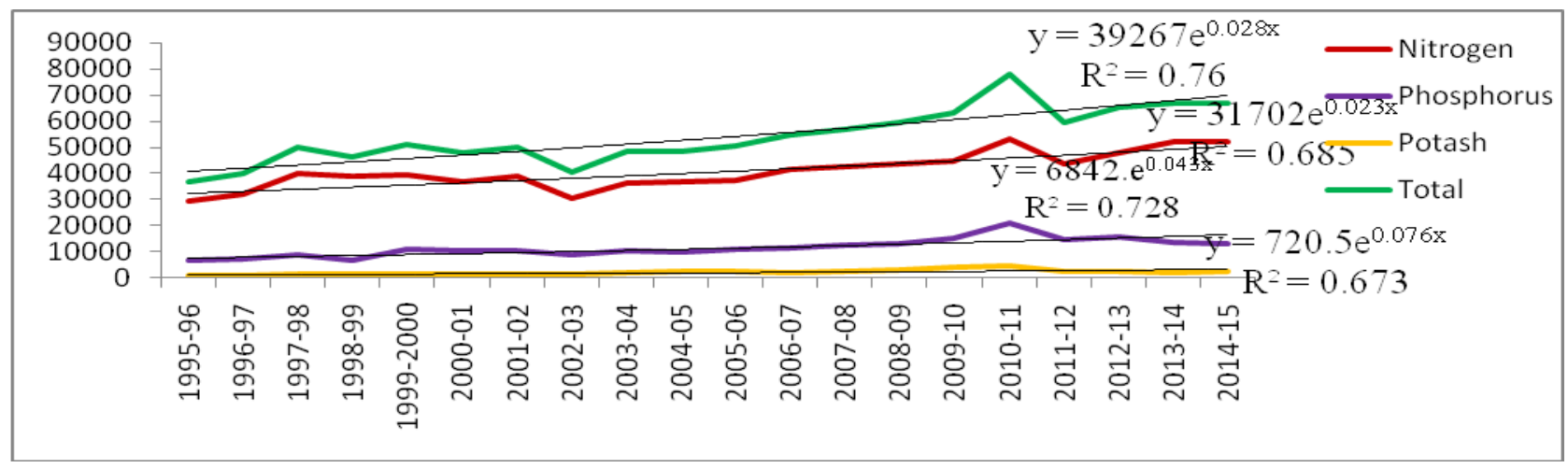

Fig.2 Trend of distribution of fertilizer (Metric Ton) in Gorakhpur District

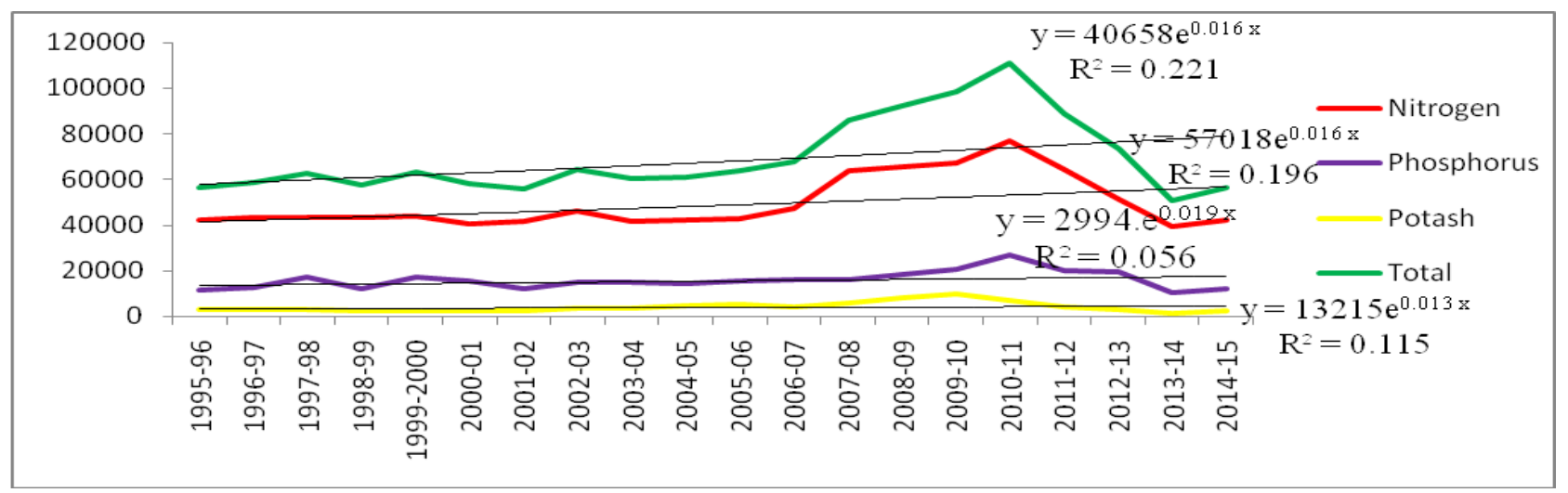

Fig.3 Trend of distribution of fertilizer (Metric Ton) in Pratapgarh District

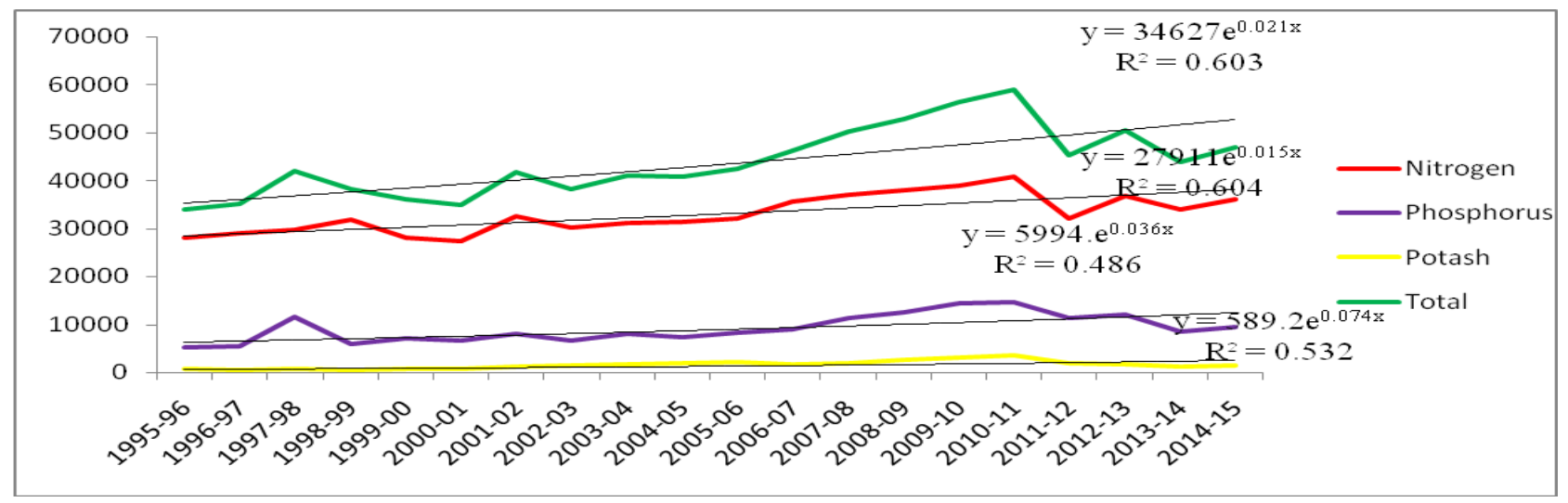

Growth rates of distribution of fertilizer (Metric Ton) in Pratapgrah district

It is evident from Table 3 that the Nitrogen, Phosphorus and Potash under of Fertilizer groups a significant and positive growth rate of Nitrogen in sub period I $(1.3 \%)$ and II period (0.9). Potash is observed of negative growth rate $(-2.3 \%)$ in sub period II and insignificant, period 1904-05 to 2013-2014 in Pratapgrah district (Fig. 3). 
In Table 3, Phosphorus distributions recorded positive and significant and highest growth rate in observed in I period $(2.8 \%)$ and highest growth rate in II period $(3.7 \%)$.

In study period 1994-95 to 2013-14 of distribution of Potash, growth rate $(8.3 \%)$ observed in positive and significant growth rate and Nitrogen $(1.7 \%)$ observed in highest growth rate, all over I period Nitrogen, Phosphorus and Potash (1.7\%), highest and lowest in II period (1.4\%).

Compound growth rate of distribution Nitrogen, Phosphorus and Potash under of Fertilizer groups was observed in district of Eastern U.P viz. Jaunpur District, Pratapgarh District and Gorakhpur district and it was found that there was positive growth rate in Potash distribution was observed in sub period 1995-96 to 2004-05 (3.3\%) while in Potash is observed of negative growth rate ($11.3 \%$ ) and significant, period 2005-06 to 2014-15 in Gorakhapur.

The Potash is observed of negative growth rate $(-1.6 \%)$ to $(-11.3 \%)$ in sub period II and in significant, period 1904-05 to 2013-2014 due to reduction of government subsidy on non-urea fertilizers.

Therefore Government should continue the subsidy on fertilizers in order to promote the use of fertilizers as their consumption on the small and marginal farms is already low. Abolition/ reduction of subsidy on fertilizers will reduce their consumption leading to poor agricultural production in the country.

\section{References}

Brij Bala; Sharma, R.K.; Sharma, S. D. (2005) Factors influencing fertilizer production and consumption in India. Indian Journal of Agricultural Research, 39(2): 146-149.

Flinn, J.C. and Shankya, P.B. (1985). A Tobit analysis of adoption and the use rates of fertilizer wheat in eastern Tarai of Nepal. Indian J. Agri. Eco., 11(3): 5257

Kalamkar, S.S., Atkare, V.G, and Shende, N.V. (2002) An Analysis of Growth Trends of Principal Crops in India. Agricultural Science Digest 22 (3): 153 $-156$.

Kannan, E., (2012). Trends in India's agricultural growth and its determinants. Asian Journal of Agriculture and Development, 8, 79-98,

Kumar P, Mittal S. (2006). Agricultural Productivity Trends in India: Sustainability Issues. Agricultural Economics Research Review 19, 71-88.

Shanthini, P and Kathirvel, N (2013). A study on farmers brand preference on the consumption of fertilizer in Tiruppur District, Tamil Nadu, Global Research Analysis

Vanpal, K.B., Pant, D.C. Burak, S.S., Shekhawat R.S. and Mehra, J. (2015). Growth and Instability in Production of Cumin in Rajasthan, Journal Agric. Res. Technol. 40 (2), pp. 309-314.

\section{How to cite this article:}

Parmeshwar Kushwaha and Rakesh Singh. 2017. Growth and Trends of Non-durable Agricultural Inputs in Eastern Uttar Pradesh: District Level Analysis. Int.J.Curr.Microbiol.App.Sci. 6(12): 102-107. doi: https://doi.org/10.20546/ijcmas.2017.612.014 